\title{
What Do Investors Care about in Strategic Alliances? An Empirical Study in the US and Japan
}

\author{
Feng Jui $\mathrm{Hsu}^{1}$, Jiunn Chiou Chiang ${ }^{2} \&$ Tsai Yi Wang ${ }^{2}$ \\ ${ }^{1}$ National Chung Hsing University, Taiwan, Taichung \\ ${ }^{2,3}$ National Taichung University of Science and Technology, Taiwan, Taichung \\ Correspondence: Jiunn Chiou Chiang, National Taichung University of Science and Technology, No.129, Sec. 3, \\ Sanmin Rd., North Dist., Taichung City 40401, Taiwan. Tel: 886-4-2219-6522. E-mail: jchiang@nutc.edu.tw
}

Received: August 22, 2013

Accepted: September 10, $2013 \quad$ Online Published: November 22, 2013

doi: 10.5539/ibr.v6n12p74

URL: http://dx.doi.org/10.5539/ibr.v6n12p74

\begin{abstract}
This study investigates investor concerns in the formation of strategic alliances, specifically concerns regarding opportunistic behavior and partner capabilities at the announcement of the alliance. Consistent with prior studies, our results show that both two partners gain in terms of abnormal returns and firm size, but that these benefits disappear within few days following the announcement, indicating that the market takes a dim view of alliances between large companies. The results suggest that investors are mostly concerned with short-term gains from speculation, rather than the ability of the alliance to increase long-term value.
\end{abstract}

Keywords: opportunistic behavior, companies' ability, strategic alliances, large-scale companies

\section{Introduction}

Firms frequently join together to create strategic alliances (S-As), pooling assets and/or technical skills to improve product development, and/or to extend market share (Hagedoon, 1993). Prior empirical studies have shown that, on average, shareholder value increases when firms announce an S-As (Chan et al., 1999; Anand \& Khanna, 2000). However, S-A is a complex and risky process between two or more firms, and many such initiatives fail to deliver anticipated benefits. This raises the question of whether investors consider the potential for failure in S-As or whether they are rather focused on short-term speculative gains. To investigate investor behavior, we focus on S-As activity in the world's two world largest economies - the US \& Japan - to identify underlying reasons for markets to confer different valuations on firms entering into an S-As.

In this study, we focus on two key factors in formulating the market's valuation: opportunistic behavior and companies' comparative advantage, which are widely discussed in the S-As literature (Kale et al., 2000; Kale et al., 2002) and influence the likelihood of the S-As successfully delivering its anticipated benefits. Furthermore, we also consider investor speculation. To identify investor opportunism and partners' comparative advantage, we consider alliances formed by two or more than two public firms of different sizes, one each from the US and Japan. To preserve its competence, the smaller partner may opportunistically take advantage of the larger partner's resources while failing to share its own core technology or information. In such circumstances, at the S-As announcement, the market may reward the smaller firm with an increased valuation, but decrease the valuation of the larger firm. Thus, we separately calculate the cumulative abnormal returns (CARs) of the smaller and larger partners at the announcement, and examine the impact of the S-A characteristics on the CARs of the respective firms. Using a sample of 427 contractual S-As events between a total of 918 US and Japanese firms, we find that, on average, stockholders in both enjoy capital gains immediately following the announcement, but that this benefit disappeared after a few days.

\section{Research Hypothesis}

Companies can benefit from S-As through sharing technology, knowledge, sales channels, and facilities. Ideally, such an arrangement will create synergies which benefit both firms. However, S-As can fail due to one or both partners entering the arrangement with the intention of exploiting the other firm's resources, assets or channels.

To protect themselves from such exploitation, partnering firms may hold back crucial assets or capabilities, hide information, or shirk their contractual obligations and responsibilities. Such opportunistic behavior may result in one partner gaining at the expense of the other partner. This study tries to infer the impact of the announcement 
of an S-As on investors. First, we consider six attributes (i.e., R\&D, licensing, manufacturing, financing, marketing agreements, and technology transfer and integration) of the S-As which may affect the stock prices of the partnering firms around the announcement day. To determine the effect of the type of S-As (Das et al., 1998), we divide those S-As events into four types: technical, manufacturing, marketing, and other. Second, relative size is an important factor when forming an S-As between a larger firm and a smaller firm on which the larger firm is dependent for innovative technologies or rare resources. The technical dependence of larger partner raises the visibility and bargaining power of the smaller firm (Merton, 1987), while the larger partner provides resources to support the requirements of the smaller partner. Thus, the smaller partner is seen as being the net beneficiary of the S-As and the announcement effect for the larger partners is equivocal. Third, S-As established between firms in different industries is a signal that the firms are seeking diversity, or that they have complementary product lines. Investors thus estimate the potential for success based on this diversification or complementariness. Empirical studies show that diversification reduces firm value (Berger \& Ofek, 1995), especially in technical alliances struck to achieve diversification. Fourth, S-As have a greater chance of success when at least one of the partner firms has experience in forming such arrangements (Anand \& Khanna, 2000), and the experienced partner can include structures and mechanisms to prevent opportunistic behavior on the part of the other partners. Finally, investment in R\&D (Chauvin \& Hirschey, 1993) is a crucial driver for growth and innovation, especially in technology-related industries. Stock markets are keenly aware of R\&D investment and such investment has a positive effect on stock returns (Chan et al., 1990). Therefore, investors may react favorably to S-As announcements from firms with high R\&D intensity.

\section{Method and Data}

Data on strategic alliances for a period of 21 years (1990-2010) was obtained from the Securities Data Corporation (SDC) database. To determine the large-scale effect, we select cross-country S-As events between US and Japan firms. We then cross-reference the partnering firms with data from the Center for Research in Security Prices (CRSP) to calculate their respective cumulative abnormal returns (CARs) and the Compustat database to obtain accounting data. This selection process produced a total of $427 \mathrm{~S}-\mathrm{A}$ events between multiple public firms, one each from the US and Japan. Types of S-As, S-As experience, and the Standard Industrial Classification (SIC) codes of the partnering firms were obtained from the SDC. Daily returns of the partnering firms were obtained from the CRSP database. Size is used as a proxy for capitalization which is calculated by multiplying the close price by the number of shares outstanding (also obtained from CRSP). Accounting data (i.e., sales and $R \& D$ expenses) were obtained from the Compustat database. To determine the announcement effect of the S-As, we used the event study approach proposed by Chan et al. (1997). The market model is estimated using data from 180 to 21 days prior to the S-As announcement day. Abnormal returns (ARs) are calculated as returns minus expected returns using the market model, and CARs are calculated by the sum of ARs over the announcement period. The $\mathrm{Z}$ statistic test is used to test the significance of the ARs and CARs. The 427 alliances (between 918 firms) were categorized as technical (251 cases), manufacturing (56), marketing (53), and other (67). Of the 918 firms surveyed, 708 belonged to the high-tech sector, while 210 were classified as traditional industries. In nearly all cases, the US partner was larger in terms of market value than the Japanese partner, and this disparity was greatest in manufacturing S-As (median 9.43 times) and smallest in technical S-As (median 7.39 times). In addition, the majority of US-Japan S-As occurred before 2000 (see Table 1).

Table 1. Summary statistics of the sample from 1990-2010

\begin{tabular}{|c|c|c|c|c|c|c|c|c|c|}
\hline & \multicolumn{9}{|c|}{ Panel A Number of Events } \\
\hline & \multirow{3}{*}{ No. of Events } & \multicolumn{2}{|c|}{ 2-digit SIC Code } & & \multicolumn{5}{|c|}{ Alliance Mode } \\
\hline & & \multirow[t]{2}{*}{ Same } & \multirow[t]{2}{*}{ Different } & \multicolumn{3}{|c|}{ Technical } & \multirow{2}{*}{$\begin{array}{l}\text { Manufac } \\
\text {-turing }\end{array}$} & \multirow[t]{2}{*}{ Marketing } & \multirow[t]{2}{*}{ Other } \\
\hline & & & & Licensing & $R \& D$ & Mixed & & & \\
\hline 1990 & 11 & 1 & 10 & 3 & 0 & 2 & 2 & 2 & 2 \\
\hline 1991 & 16 & 8 & 8 & 1 & 1 & 7 & 2 & 4 & 1 \\
\hline 1992 & 66 & 30 & 36 & 13 & 15 & 19 & 5 & 12 & 2 \\
\hline 1993 & 54 & 17 & 37 & 3 & 23 & 13 & 6 & 6 & 3 \\
\hline 1994 & 55 & 19 & 36 & 0 & 21 & 20 & 5 & 5 & 4 \\
\hline
\end{tabular}




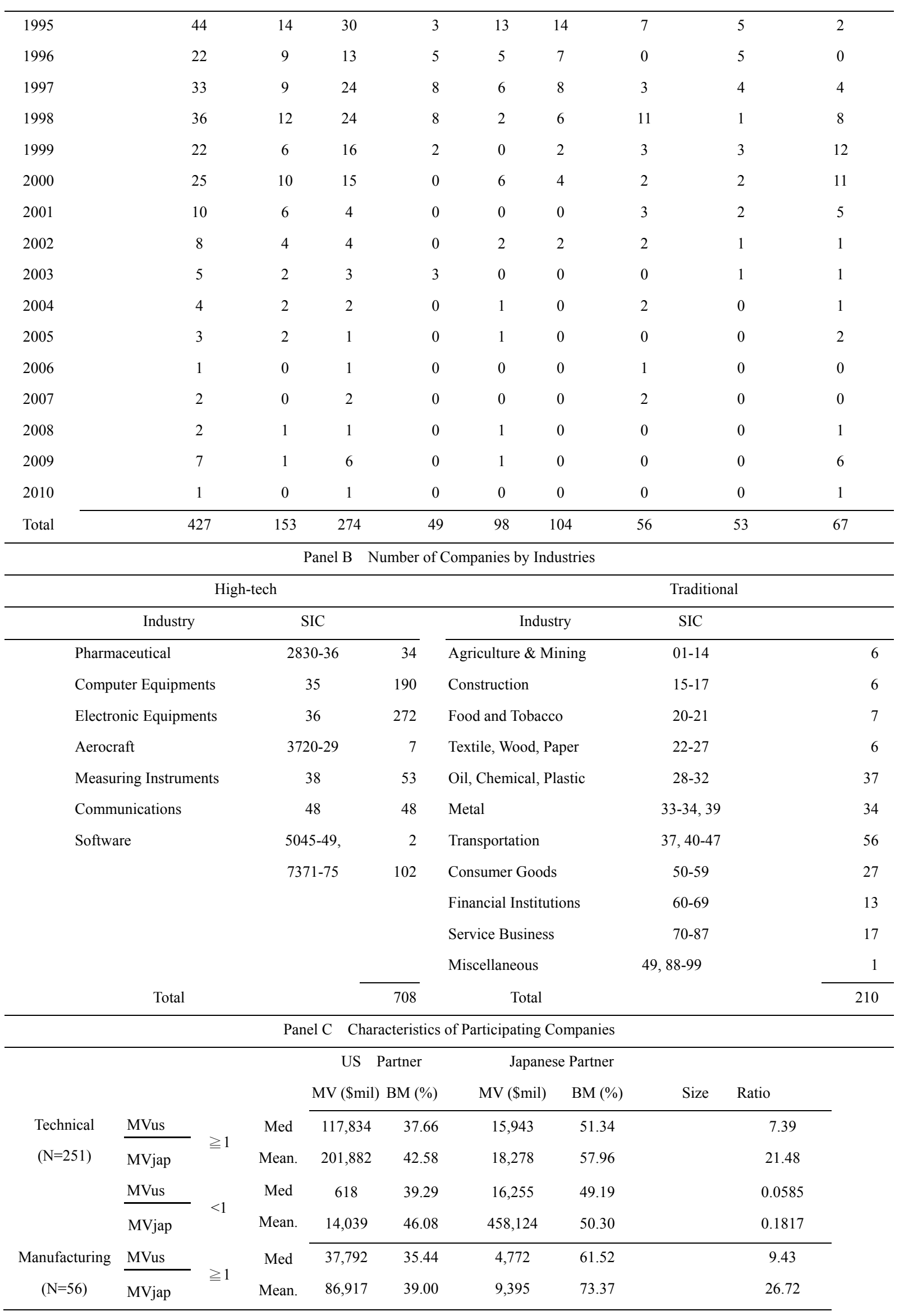




\begin{tabular}{|c|c|c|c|c|c|c|c|c|}
\hline & MVus & & Med & 1,385 & 45.41 & 9,204 & 51.29 & 0.3657 \\
\hline & MVjap & $<1$ & Mean. & 3,838 & 58.19 & 9,899 & 54.57 & 0.3889 \\
\hline \multirow{4}{*}{$\begin{array}{c}\text { Marketing } \\
(\mathrm{N}=53)\end{array}$} & MVus & \multirow{2}{*}{$\geqq 1$} & Med & 62,409 & 40.42 & 7,243 & 58.15 & 8.85 \\
\hline & MVjap & & Mean. & 202,457 & 46.38 & 11,437 & 64.68 & 112.72 \\
\hline & MVus & \multirow{2}{*}{$<1$} & Med & 442 & 47.87 & 13,260 & 44.51 & 0.0336 \\
\hline & MVjap & & Mean. & 1,827 & 54.20 & 19,810 & 52.40 & 0.1026 \\
\hline \multirow{4}{*}{$\begin{array}{l}\text { Other } \\
(\mathrm{N}=67)\end{array}$} & MVus & \multirow{2}{*}{$\geqq 1$} & Med & 55,144 & 26.97 & 6,403 & 54.03 & 8.14 \\
\hline & MVjap & & Mean. & 174,710 & 37.55 & 14,118 & 57.66 & 30.42 \\
\hline & MVus & \multirow{2}{*}{$<1$} & Med & 5,959 & 39.48 & 33,233 & 38.81 & 0.1831 \\
\hline & MVjap & & Mean. & 17,797 & 50.78 & 964,361 & 68.57 & 0.2961 \\
\hline
\end{tabular}

The sample contains strategic alliances formed by US and Japan public companies and completed during 1990-2010. The larger and smaller partners of an alliance are judged by the market values (MVs) of their common stocks on the 21th day prior to the alliance announcement. The mode of alliances (technical, manufacturing, marketing, and others) indicates the property of the cooperative agreement. Mixed denotes more than two types of alliances. In Panel C, MV is the market value of common equity (million \$) on the 21 th day prior to the alliance announcement, and BM denotes the book-to-market ratio. Size ratio is the smaller partner's MV divided by the larger partner's MV. ${ }^{*}{ }^{\dagger}$, and $\neq$ denote $Z$-value significant at the $10 \%, 5 \%$ and $1 \%$, respectively.

\section{Result and Discussions}

In table 2, the pre-announcement effect is significantly negative for both the US partners $(\operatorname{CARs}(-20,-11)=-0.95 \%, p<0.05)$ and Japan partners $(\operatorname{CARs}(-20,-11)=-0.57 \%, p<0.05)$. However, closer to the announcement day, the pre-announcement effect $(\operatorname{CARs}(-10,-2)$ is respectively $-0.49 \%$ and $-0.34 \%$ for US partners and Japan partners. Although the CARs are still negative, the negative return effect shrinks. Interestingly, the announcement effect near the announcement day is positive for the US partners $(\operatorname{CARs}(-1,+1)=0.36 \%)$ and significantly positive for the Japan partners $(\operatorname{CARs}(-1,+1)=0.49 \%, p<0.01)$. Furthermore, on the announcement day, the announcement effect is significantly positive for both the US partners $(\operatorname{ARs}(0)=0.4 \%, p<0.05)$ and Japan partners $(\operatorname{ARs}(0)=0.32 \%, p<0.01)$. This indicates either information leakage prior to the announcement day or that investors are reacting in real time to the S-A events. The post-announcement effect for US partners is negative and statistically significant $(\operatorname{CARs}(2,10)=-1.04 \%, p<0.05$ and $\operatorname{CARs}(11,20)=-0.95 \%, p<0.1)$, while the Japan partners experience negative $\operatorname{CARs}(2,10)$ and positive $\operatorname{CARs}(11,20)$ with statistical insignificance $(\operatorname{CARs}(2,10)=-0.16 \%$ and CARs $(11,20)=0.14 \%)$. This wealth transfer effect (from the US partners to the Japan partners) implies that investors believe that S-As are harmful to US partners but advantageous to Japan partners (consistent with Anand \& Khanna, 2000). When separates the S-As into the technical, manufacturing, marketing, and others groups. The CAR patterns for S-As in the various categories (technical, manufacturing, marketing and other) are similar, except that the US partners in the marketing group experience positive CARs before and after the announcement day. This indicates that investors prefer marketing alliances and such S-As events will benefit both parties. Because the majority of the S-As events between the US and Japan occurred between 1990 and 2000, we also tested the announcement effect in different periods (i.e., 1990-2000 and 2001-2012). Again, the CARs patterns among two periods were similar (see Figure 1-Figure 3).

Table 2. Announcement effects of strategic alliances

\begin{tabular}{ccrrrrr}
\hline & \multicolumn{3}{c}{ Panel A } & Announcement Effect $(\mathrm{N}=427)$ \\
\hline & & \multicolumn{2}{c}{ US Partner } & \multicolumn{3}{c}{ Japanese Partner } \\
Day & AR (CAR) & \multicolumn{1}{c}{ p-value } & \% of CAR $>0$ & AR (CAR) & p-value & $\%$ of CAR $>0$ \\
\hline$(20,11)$ & $-0.95 \%$ & $\left(0.054^{*}\right)$ & $43.33 \%$ & $-0.57 \%$ & $\left(0.036^{\dagger}\right)$ & $44.02 \%$ \\
$(10,2)$ & $-0.49 \%$ & $(0.318)$ & $46.44 \%$ & $-0.34 \%$ & $(0.150)$ & $48.50 \%$ \\
1 & $0.11 \%$ & $(0.523)$ & $46.00 \%$ & $0.11 \%$ & $(0.258)$ & $51.07 \%$ \\
0 & $0.40 \%$ & $\left(0.035^{\dagger}\right)$ & $50.89 \%$ & $0.32 \%$ & $\left(0.001^{\ddagger}\right)$ & $53.63 \%$ \\
\hline
\end{tabular}




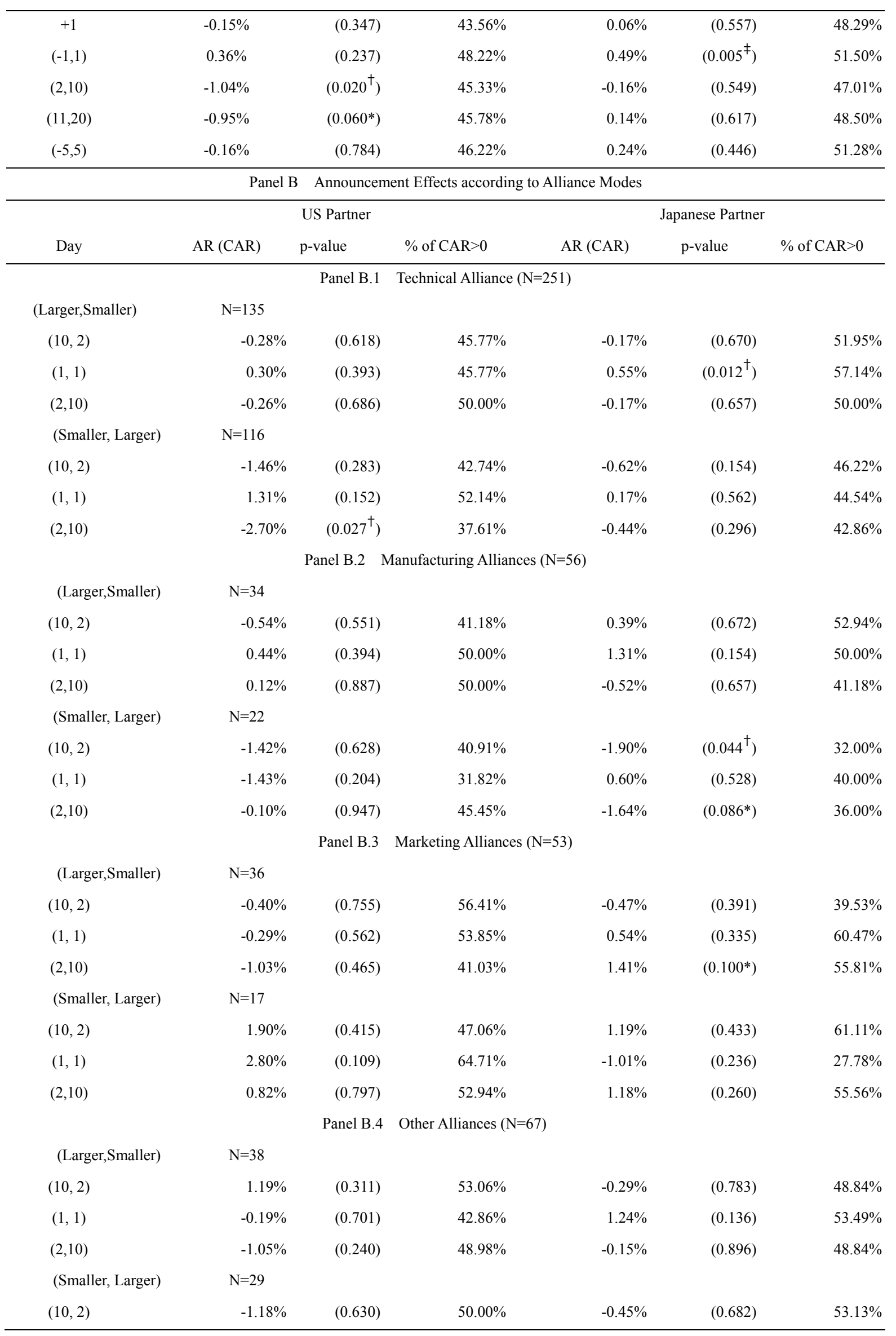




\begin{tabular}{|c|c|c|c|c|c|c|}
\hline$(1,1)$ & $-1.51 \%$ & $(0.309)$ & $46.67 \%$ & $0.16 \%$ & $(0.853)$ & $59.38 \%$ \\
\hline$(2,10)$ & $-1.30 \%$ & $(0.463)$ & $43.33 \%$ & $-0.34 \%$ & $(0.840)$ & $43.75 \%$ \\
\hline \multicolumn{7}{|c|}{ Panel C Announcement Effects according to Different period } \\
\hline \multirow[b]{2}{*}{ Day } & \multicolumn{3}{|c|}{ US Partner } & \multicolumn{3}{|c|}{ Japanese Partner } \\
\hline & $\mathrm{AR}(\mathrm{CAR})$ & p-value & $\%$ of $\mathrm{CAR}>0$ & $\mathrm{AR}(\mathrm{CAR})$ & p-value & $\%$ of $\mathrm{CAR}>0$ \\
\hline \multicolumn{7}{|c|}{ Panel C.1 1990-1999 $(\mathrm{N}=359)$} \\
\hline (Larger,Smaller) & $\mathrm{N}=208$ & & & & & \\
\hline$(10,2)$ & $-0.36 \%$ & $(0.419)$ & $45.98 \%$ & $-0.29 \%$ & $(0.341)$ & $48.31 \%$ \\
\hline$(1,1)$ & $-0.05 \%$ & $(0.822)$ & $45.54 \%$ & $0.76 \%$ & $\left(0.001^{\ddagger}\right)$ & $57.63 \%$ \\
\hline$(2,10)$ & $-0.37 \%$ & $(0.400)$ & $48.66 \%$ & $0.09 \%$ & $(0.801)$ & $50.00 \%$ \\
\hline (Smaller, Larger) & $\mathrm{N}=151$ & & & & & \\
\hline$(10,2)$ & $-0.73 \%$ & $(0.520)$ & $42.76 \%$ & $-0.33 \%$ & $(0.414)$ & $48.45 \%$ \\
\hline$(1,1)$ & $1.04 \%$ & $(0.144)$ & $51.97 \%$ & $0.18 \%$ & $(0.513)$ & $44.10 \%$ \\
\hline$(2,10)$ & $-1.21 \%$ & $(0.223)$ & $44.08 \%$ & $-0.17 \%$ & $(0.654)$ & $44.10 \%$ \\
\hline \multicolumn{7}{|c|}{ Panel C.2 2000-2010 (N=68) } \\
\hline (Larger,Smaller) & $\mathrm{N}=35$ & & & & & \\
\hline$(10,2)$ & $1.65 \%$ & $(0.221)$ & $60.00 \%$ & $0.64 \%$ & $(0.572)$ & $57.89 \%$ \\
\hline$(1,1)$ & $1.21 \%$ & $(0.172)$ & $55.00 \%$ & $0.67 \%$ & $(0.456)$ & $47.37 \%$ \\
\hline$(2,10)$ & $-1.04 \%$ & $(0.527)$ & $47.50 \%$ & $-0.30 \%$ & $(0.766)$ & $47.37 \%$ \\
\hline (Smaller, Larger) & $\mathrm{N}=33$ & & & & & \\
\hline$(10,2)$ & $-2.79 \%$ & $(0.244)$ & $50.00 \%$ & $-1.84 \%$ & $\left(0.038^{\dagger}\right)$ & $39.39 \%$ \\
\hline$(1,1)$ & $-0.99 \%$ & $(0.557)$ & $41.18 \%$ & $-0.22 \%$ & $(0.786)$ & $48.48 \%$ \\
\hline$(2,10)$ & $-4.67 \%$ & $\left(0.013^{\dagger}\right)$ & $26.47 \%$ & $-1.68 \%$ & $(0.261)$ & $39.39 \%$ \\
\hline
\end{tabular}

Panel D Changes in Wealth (Million \$)

Larger, Smaller

\begin{tabular}{|c|c|c|c|c|c|}
\hline \multicolumn{2}{|c|}{ US Partner } & \multicolumn{2}{|c|}{ Japanese Partner } & \multicolumn{2}{|c|}{ Portfolio } \\
\hline EW MV & EW $\Delta \mathrm{MV}$ & EW MV & EW $\Delta \mathrm{MV}$ & EW $\Delta \mathrm{MV}$ & VW $\Delta \mathrm{MV}$ \\
\hline 179,006 & 167.02 & 15,666 & -14.58 & 74.54 & -0.56 \\
\hline \multicolumn{6}{|c|}{ Smaller, Larger } \\
\hline \multicolumn{2}{|c|}{ US Partner } & \multicolumn{2}{|c|}{ Japan Partner } & \multicolumn{2}{|c|}{ Portfolio } \\
\hline EW MV & $\mathrm{EW} \Delta \mathrm{MV}$ & EW MV & EW $\Delta \mathrm{MV}$ & EW $\Delta \mathrm{MV}$ & VW $\Delta \mathrm{MV}$ \\
\hline 12,364 & 11.59 & 421,651 & $-1,776$ & -901.51 & -138.54 \\
\hline \multicolumn{6}{|c|}{ Overall $(\mathrm{N}=427)$} \\
\hline \multicolumn{2}{|c|}{ US Partner } & \multicolumn{2}{|c|}{ Japanese Partner } & \multicolumn{2}{|c|}{ Portfolio } \\
\hline EW MV & EW $\Delta \mathrm{MV}$ & EW MV & EW $\Delta \mathrm{MV}$ & EW $\Delta \mathrm{MV}$ & VW $\Delta \mathrm{MV}$ \\
\hline 110,127 & 102.77 & 183,958 & -745.13 & -329.49 & -35.68 \\
\hline
\end{tabular}

There are in total 427 events of strategic alliances consisting of US and Japan companies completed during 1990-2010. The larger and smaller partners of an alliance are judged by their market values (MVs) on the 21th day prior to the alliance announcement. Panels A and B report cumulative abnormal returns (CARs) around the alliance announcement day. In Panel C, EW MV is the average dollar change in

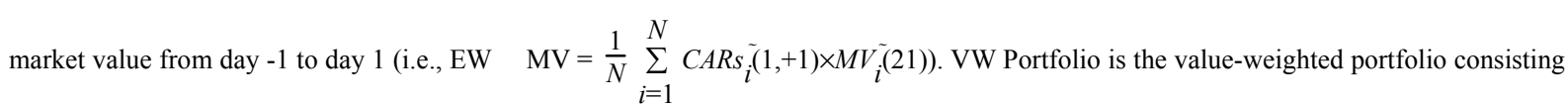


of both the larger and smaller partners (VW $\quad \mathrm{MV}=\sum_{i=1}^{2 N} w_{i} \times \quad M V_{i}$, where $w_{i}$ is the weight of company $i$ 's market value). ${ }^{*},{ }^{\dagger}$, and ${ }^{\ddagger}$ denote $Z$-value significant at the $10 \%, 5 \%$ and $1 \%$, respectively.

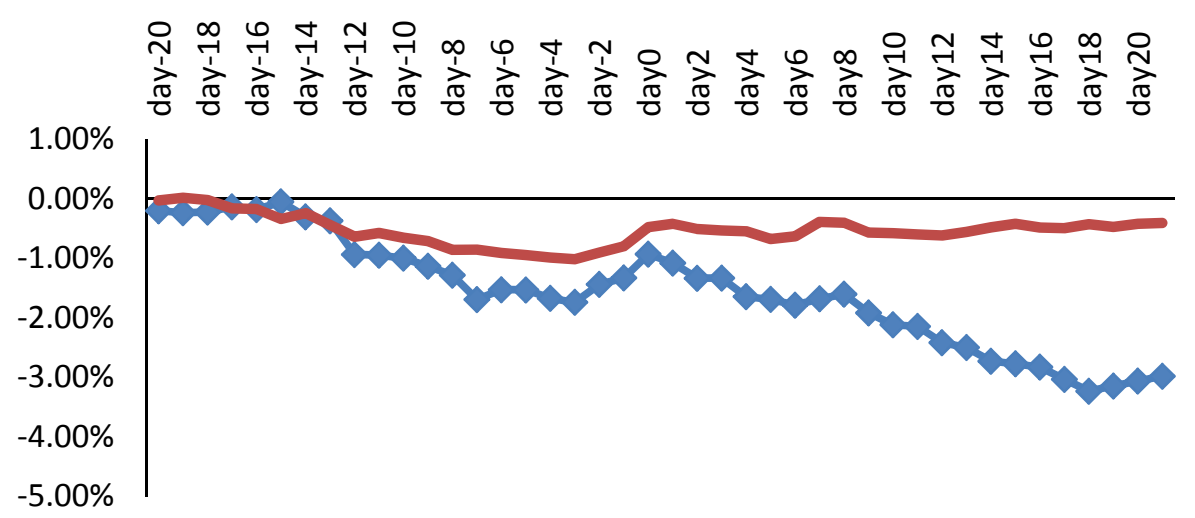

$\leadsto$ Over all Return-US $\quad$ Over all Return-Japan

Figure 1. CARs around alliance announcements from 1990-2010

There are totally 427 events of strategic alliances consisting of US and Japan companies for 1990-2010.

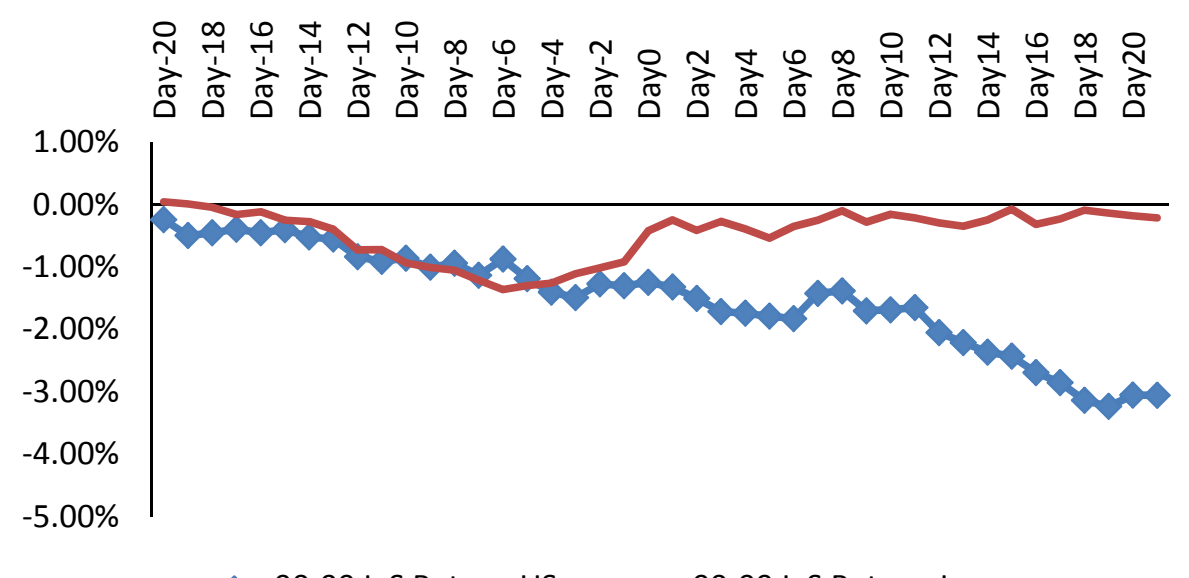

Figure 2. CARs around alliance announcements from 1990-1999

There are totally 359 events of strategic alliances consisting of US and Japan companies for 1990-1999.

To investigate the relative size effect around the S-As events, we ranked the partner firms by market value, resulting in three groups: two large firms, two small firms, and one large and one small firm. Firms in the small-large group enjoy CARs which are significantly positive and greater than those of the two other groups (5.01\% in technical, $p<0.05 ; 4.21 \%$ in manufacturing, $p<0.01 ; 3.76 \%$ in marketing, $p<0.01)$. These results are consistent with our prior results and imply that a small firm forming an S-As with a large firm can earn greater returns due to the reference effect and by engaging in opportunistic behavior. In addition, to exhibit the impact of industry relatedness on the announcement effect, we sorted the sample according to whether or not the partnering firms shared the same first 2-digit SIC code. For technical S-As, the larger partners of both the related and unrelated groups experienced a loss of value. However, marketing S-As exhibit a different CARs pattern from technical S-As. Marketing partners show a wealth transfer effect in the related group and both partners experience positive CARs in the unrelated group. Unrelated marketing S-As are partner a manufacturer and a 
distributor to sell products or services in new markets. The positive announcement effect for both partners indicates that investors believe that the S-As can create extra sales (not tabled).

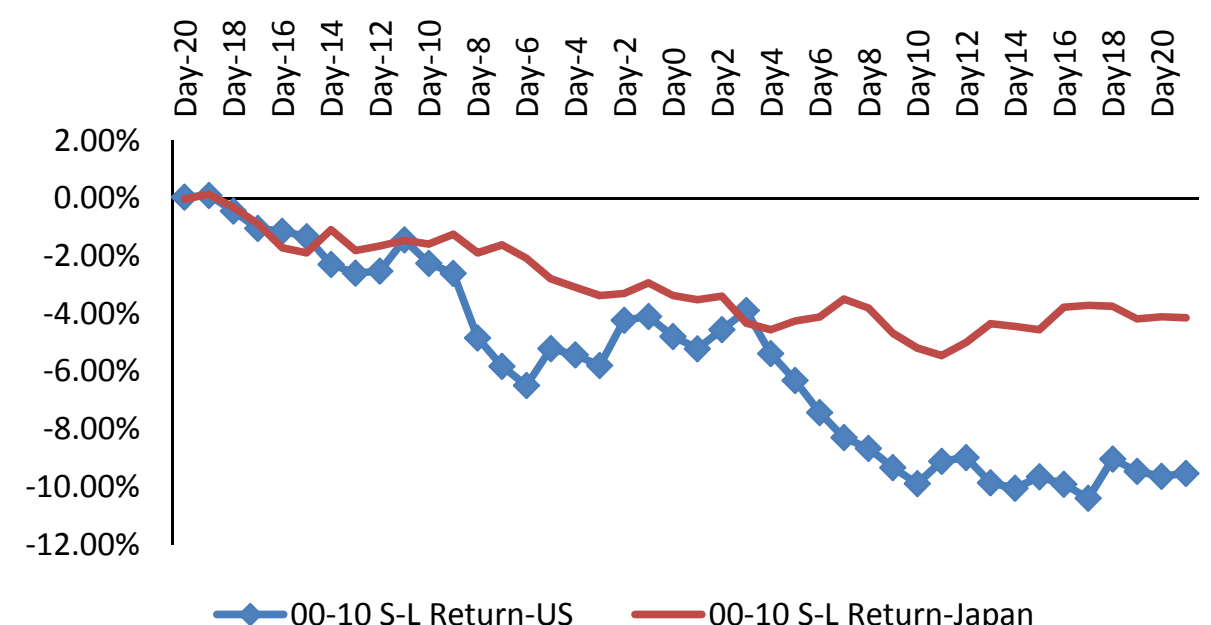

Figure 3. CARs around alliance announcements from 2000-2010

There are totally 68 events of strategic alliances consisting of US and Japan companies for 2000-2010.

Table 3. Announcement effects according to firm size

\begin{tabular}{|c|c|c|c|c|c|}
\hline & & \multicolumn{2}{|c|}{ High Size Ratio } & \multicolumn{2}{|c|}{ Low Size Ratio } \\
\hline & & Larger Partner & Smaller Partner & Larger Partner & Smaller Partner \\
\hline Technical & CARs $(-1,+1)$ & $-0.55 \%$ & $0.51 \%$ & $-0.57 \%$ & $5.01 \%$ \\
\hline$(\mathrm{N}=251)$ & $\mathrm{p}$-value & $(0.191)$ & $\left(0.021^{\dagger}\right)$ & $(0.104)$ & $\left(0.000^{\mp}\right)$ \\
\hline Manufacturing & CARs $(-1,+1)$ & $-0.11 \%$ & $2.03 \%$ & $0.45 \%$ & $4.21 \%$ \\
\hline$(\mathrm{N}=56)$ & $\mathrm{p}$-value & $(0.787)$ & $\left(0.004^{\ddagger}\right)$ & $(0.471)$ & $\left(0.005^{\ddagger}\right)$ \\
\hline Marketing & CARs $(-1,+1)$ & $1.03 \%$ & $0.89 \%$ & $-0.18 \%$ & $3.76 \%$ \\
\hline$(\mathrm{N}=53)$ & p-value & $\left(0.096^{*}\right)$ & $(0.303)$ & $(0.705)$ & $\left(0.001^{\ddagger}\right)$ \\
\hline
\end{tabular}

There are in total 427 events of strategic alliances consisting of US and Japan companies completed during 1990-2010. The larger and smaller partners of an alliance are judged by their market values (MVs) on the 21 th day prior to the alliance announcement. ${ }^{*},{ }^{\dagger}$, and ${ }^{\ddagger}$ denote $Z$-value significant at the $10 \%, 5 \%$ and $1 \%$, respectively.

To determine the connection between $R \& D$ intensity and the announcement effect, we use a ratio of $R \& D$ expenses to sales to separate both partners into high and low R\&D groups. For technical S-As, the announcement effect of the large partners is positive (CARs $(-1,+1)=0.16 \%$ ) if both partners have high R\&D intensity. This result is consistent with the argument that investors take a positive view of S-As between two high R\&D intensity firms because they view such an alliance as creating useful synergies. Furthermore, as a proxy for experience with strategic alliances, we traced whether either of the partnering firms had been involved in another S-As within the five years preceding the S-As announcement in question. The empirical results indicate that larger, experienced firms have a negative announcement effect for technical S-As, but a positive announcement effect for marketing S-As. However, if the larger partner is experienced and the smaller partner is not, then the larger partner experiences positive CARs $(0.06 \%)$ while the smaller partner experiences lower CARs $(1.28 \%)$ in technical S-As. This implies that, in technical alliances, experienced larger partners may take advantage of their small partners. 
Table 4. Announcement effects according to R\&D intensity and alliance experience

\begin{tabular}{|c|c|c|c|c|c|c|c|c|c|}
\hline \multicolumn{10}{|c|}{ Panel A CARs by R\&D-to-Sale Ratio } \\
\hline & & \multicolumn{2}{|c|}{$\mathrm{H}-\mathrm{H}$} & \multicolumn{2}{|c|}{$\mathrm{H}-\mathrm{L}$} & \multicolumn{2}{|c|}{ L-H } & \multicolumn{2}{|c|}{ L-L } \\
\hline & & $\begin{array}{l}\text { Larger } \\
\text { Partner }\end{array}$ & $\begin{array}{l}\text { Smaller } \\
\text { Partner }\end{array}$ & $\begin{array}{l}\text { Larger } \\
\text { Partner }\end{array}$ & $\begin{array}{l}\text { Smaller } \\
\text { Partner }\end{array}$ & $\begin{array}{l}\text { Larger } \\
\text { Partner }\end{array}$ & $\begin{array}{l}\text { Smaller } \\
\text { Partner }\end{array}$ & $\begin{array}{l}\text { Larger } \\
\text { Partner }\end{array}$ & $\begin{array}{l}\text { Smaller } \\
\text { Partner }\end{array}$ \\
\hline Technical & $\operatorname{CARs}(1,+1)$ & $0.16 \%$ & $5.58 \%$ & $-0.37 \%$ & $1.98 \%$ & $-0.49 \%$ & $3.88 \%$ & $-0.79 \%$ & $2.51 \%$ \\
\hline$(\mathrm{N}=251)$ & p-value & $(0.615)$ & $\left(0.000^{\ddagger}\right)$ & $(0.420)$ & $\left(0.002^{\ddagger}\right)$ & $\left(0.092^{*}\right)$ & $\left(0.000^{\ddagger}\right)$ & $\left(0.011^{\dagger}\right)$ & $\left(0.009^{\ddagger}\right)$ \\
\hline Marketing & $\operatorname{CARs}(1,+1)$ & $-0.18 \%$ & $2.78 \%$ & $1.54 \%$ & $\%$ & $0.31 \%$ & $3.95 \%$ & $0.61 \%$ & $1.44 \%$ \\
\hline$(\mathrm{N}=53)$ & p-value & $(0.815)$ & $(0.113)$ & $(0.115)$ & $(0.521)$ & $(0.487)$ & $\left(0.013^{\dagger}\right)$ & $(0.350)$ & $(0.172)$ \\
\hline \multicolumn{10}{|c|}{ Panel B CARs by Companies' Experience } \\
\hline & & \multicolumn{2}{|c|}{ Yes-Yes } & \multicolumn{2}{|c|}{ Yes-No } & \multicolumn{2}{|c|}{ No-Yes } & \multicolumn{2}{|c|}{ No-No } \\
\hline & & $\begin{array}{l}\text { Larger } \\
\text { Partner }\end{array}$ & $\begin{array}{l}\text { Smaller } \\
\text { Partner }\end{array}$ & $\begin{array}{l}\text { Larger } \\
\text { Partner }\end{array}$ & $\begin{array}{l}\text { Smaller } \\
\text { Partner }\end{array}$ & $\begin{array}{l}\text { Larger } \\
\text { Partner }\end{array}$ & $\begin{array}{l}\text { Smaller } \\
\text { Partner }\end{array}$ & $\begin{array}{l}\text { Larger } \\
\text { Partner }\end{array}$ & $\begin{array}{l}\text { Smaller } \\
\text { Partner }\end{array}$ \\
\hline Technical & $\operatorname{CARs}(1,+1)$ & $-0.15 \%$ & $3.71 \%$ & $0.06 \%$ & $1.28 \%$ & $0.21 \%$ & $1.41 \%$ & $-0.61 \%$ & $5.55 \%$ \\
\hline$(\mathrm{N}=251)$ & $\mathrm{p}$-value & $(0.355)$ & $\left(0.000^{\ddagger}\right)$ & $\left(0.068^{*}\right)$ & $\left(0.091^{*}\right)$ & $(0.841)$ & $(0.181)$ & $(0.211)$ & $\left(0.049^{\ddagger}\right)$ \\
\hline Marketing & $\operatorname{CARs}(1,+1)$ & $0.86 \%$ & $3.78 \%$ & $0.51 \%$ & $3.81 \%$ & $0.81 \%$ & $5.22 \%$ & $\sim 1 \%$ & $0.35 \%$ \\
\hline$(\mathrm{N}=53)$ & p-value & $\left(0.041^{\dagger}\right)$ & $\left(0.003^{\ddagger}\right)$ & $(0.584)$ & $\left(0.000^{\ddagger}\right)$ & $(0.615)$ & $(0.411)$ & $(0.412)$ & $(0.516)$ \\
\hline
\end{tabular}

There are in total 427 events of strategic alliances consisting of US and Japan companies completed during 1990-2010. In Panel A, the larger and smaller partners, are evenly separated into the high and low R\&D-to-sales groups, respectively. In panel B, Yes (No) denotes that the partner had at least one (no) alliance experience within the five years before the alliance announcement. * ${ }^{\dagger}$, and ${ }^{\ddagger}$ denote $Z$-value significant at the $10 \%, 5 \%$ and $1 \%$, respectively.

\section{Conclusions}

This study investigates investor response to the formation of 427 strategic alliances between two or more than two of US and Japanese companies between 1990 and 2010, along with variations of the announcement effect based on four primary alliance attributes. On average, cumulative abnormal returns (CARs) of the larger and smaller partners are respectively negative and positive. Furthermore, post-announcement CARs for the smaller partner are positive, while those for the larger partner remain negative. These results implies a wealth transfer effect from the larger partners to the smaller partners, indicating that investors are apprehensive about the smaller partner engaging in opportunistic behavior. We also find that inexperienced smaller partners teamed up with experienced larger firms tend to have lower CARs around the announcement. Furthermore, if both the larger and smaller firms are R\&D intense, the CARs for both are positive. However, in other alliance types, bigger firms have negative CARs, while the smaller firms have positive CARs. This indicates that investors pay little attention to the partners' comparative advantage to increase value at the time of the announcement. Overall, we conclude that investors are mostly concerned about the presence of opportunistic behavior.

\section{References}

Anand, B. N., \& Khanna, T. (2000). Do firms learn to create value? The case of alliances. Strategic Management Journal, $21(3)$, http://dx.doi.org/10.1002/(SICI)1097-0266(200003)21:3<295::AID-SMJ91>3.0.CO;2-O

$295-315$.

Berger, P. G., \& Ofek, E. (1995). Diversification's effect on firm value. Journal of financial economics, 37(1), 39-65. http://dx.doi.org/10.1016/0304-405X(94)00798-6

Chan, S. H., Kensinger, J. W., Keown, A. J., \& Martin, J. D. (1997). Do strategic alliances create value? Journal of Financial Economics, 46(2), 199-221. http://dx.doi.org/10.1016/S0304-405X(97)00029-9

Chan, S. H., Kensinger, J. W., Keown, A. J., \& Martin, J. D. (1999). When do strategic alliances create shareholder value? Journal of Applied Corporate Finance, 11(4), 82-87. http://dx.doi.org/10.1111/j.1745-6622.1999.tb00517.x 
Chan, S. H., Martin, J. D., \& Kensinger, J. W. (1990). Corporate research and development expenditures and share value. Journal of Financial Economics, 26(2), 255-276. http://dx.doi.org/10.1016/0304-405X(90)90005-K

Chauvin, K. W., \& Hirschey, M. (1993). Advertising, R\&D expenditures and the market value of the firm. Financial Management, 128-140. http://dx.doi.org/10.2307/3665583

Das, S., Sen, P. K., \& Sengupta, S. (1998). Impact of strategic alliances on firm valuation. Academy of Management Journal, 41(1), 27-41. http://dx.doi.org/10.2307/256895

Hagedoorn, J. (1993). Understanding the rationale of strategic technology partnering: Nterorganizational modes of cooperation and sectoral differences. Strategic Management Journal, 14(5), 371-385. http://dx.doi.org/10.1002/smj.4250140505

Kale, P., Singh, H., \& Perlmutter, H. (2000). Learning and protection of proprietary assets in strategic alliances: building relational capital. Strategic Management Journal, 21(3), 217-237.

Kale, P., Dyer, J. H., \& Singh, H. (2002). Alliance capability, stock market response, and long-term alliance success: the role of the alliance function. Strategic Management Journal, 23(8), 747-767. http://dx.doi.org/10.1002/smj.248

Merton, R. C. (1987). A simple model of capital market equilibrium with incomplete information. The Journal of Finance, 42(3), 483-510. http://dx.doi.org/10.1111/j.1540-6261.1987.tb04565.x

\section{Copyrights}

Copyright for this article is retained by the author(s), with first publication rights granted to the journal.

This is an open-access article distributed under the terms and conditions of the Creative Commons Attribution license (http://creativecommons.org/licenses/by/3.0/). 